\title{
MUTUAL LEGAL ASSISTANCE TREATIES (MLATS) SEBAGAI INSTRUMEN PEMBERANTASAN KEJAHATAN INTERNASIONAL
}

\author{
Oleh: \\ Noer Indriati \\ Fakultas Hukum Universitas Jenderal Soedirman Purwokerto
}

\begin{abstract}
International contractual law is an order which must respect and adhered by pertinent of the parties in agreement. The formal and informal relation between the citizen or corporate have very intensively. International badness which pass boundaries jurisdiction of the state have increase in the form which is sophisticated and the frequency which progressively often. Because of international badness which have more progressively is needed cooperation between the state which it is more coordinated as straightening of law. Mutual Legal Assistance Treaties (MLATS) emerge because eradication of insufficient badness upheld by agreement of extradition. Form of Mutual Legal Assistance Treaties (MLATS) have agreed on, for example United Nations Convention Against Corruption Year 2003, United nations Conventions Against Transnational Organized Crime Year 2000. While in the level of ASEAN, Treaty Mutual Legal Assistance in Criminal Matters year 2004.
\end{abstract}

Kata kunci: kejahatan internasional, perjanjian internasional

\section{A. Pendahuluan}

Perkembangan kejahatan transnasional dan kejahatan internasional merupakan karakteristik perkembangan hukum pidana dewasa ini. Perkembang-an kejahatan tersebut telah memberi-kan dampak luas dan mendasar, selain terhadap kehidupan manusia, juga terhadap asas-asas hukum, norma dan lembaga yang berkaitan dengan penerapan hukum pidana dalam me-nanggulangi kejahatan tersebut. Dilihat dari perkembangan dan asal-usul kejahatan internasional, maka kejahatan internasional dapat dibedakan dalam 3 (tiga) golongan, yaitu:

1. Kejahatan internasional yang berasal dari kebiasaan yang berkembang dalam praktik hukum inter-nasional.

2. Kejahatan internasional yang berasal dari konvensi-konvensi internasional.

3. Kejahatan internasional yang lahir dari sejarah perkembangan konvensi mengenai HAM.

Kewenangan membuat perjanjian internasional secara khusus dalam piagam Perserikatan Bangsa-bangsa, tidak ada ketentuan yang mengaturnya.
Pada era global dewasa ini, batas-batas negara sudah sangat maya, dalam arti hubungan internasional telah sangat dinamis sehingga batas-batas nasional seolah-olah dengan mudah dapat ditembus dalam hitungan waktu yang sangat cepat. Masyarakat internasional dalam era globalisasi seperti sekarang ini dengan didukung oleh kemajuan teknologi, khususnya teknologi informasi, telekomunikasi, dan transportasi, timbulnya kejahatan-kejahatan yang berdemensi internasional ini akan semakin meningkat baik secara kuantitatif mau pun kualitatif. Untuk mengatasinya tidaklah cukup hanya dilakukan oleh negara secara sendiri-sendiri, tetapi dibutuhkan kerjasama yang terpadu baik secara bilateral maupun multilateral. Salah satu lembaga hukum yang dipandang dapat menanggulangi kejahatan yang berdemensi internasional ini adalah ekstradisi. Oleh karena itu, lembaga ekstradisi muncul ke permukaan seolah-olah ekstradisi sebagai lembaga hukum yang ampuh untuk menyelesaikannya. ${ }^{1}$

\footnotetext{
I Wayan Parthiana, 2004, Hukum Pidana Internasional dan Ekstradisi, Bandung: Penerbit Yrama Widya, hlm. 127
} 
Upaya penegakkan hukum guna memberantas kejahatan internasional, masyarakat internasional tidaklah cukup dengan melakukan perjanjian ekstradisi. Hal ini perlu pula ditinjau kecenderungan negara-negara dalam pemberantasan kejahatan internasional lebih memilih menggunakan perjanjian-perjanjian lain yang tidak kalah penting dan erat kaitannya dengan kasus-kasus yang terjadi.

Berdasarkan latar belakang di atas, maka dapat dirumuskan permasalahan sebagai berikut: upaya negara-negara dalam memberantas kejahatan inter-nasional melalui Mutual Legal Assistance Treaties (MLATs)

\section{B. Pembahasan}

\section{Pengertian Kejahatan Internasional}

Belum terdapat satu ketentuan di dalam hukum internasional baik dalam perjanjian internasional maupun ke-biasaan internasional yang menetapkan istilah "international crimes". ${ }^{2}$ Pe-ngertian istilah "transnational" atau "transnasional" (Bahasan Indonesia), untuk pertama kali diperkenalkan oleh Phillip C. Yessup, seorang ahli hukum internasional yang sangat terkenal dalam lingkungan para ahli hukum sedunia. Yessup menegaskan bahwa, selain istilah hukum internasional atau international law, digunakan istilah nasional atau transnasional yang dirumuskan, semua hukum yang mengatur semua tindakan atau kejadian yang melampaui batas territorial. ${ }^{3}$

Pengertian istilah tersebut kemudian di gunakan dalam salah satu Keputusan Kongres PBB VIII, tentang Pencegahan Kejahatan dan Perlakuan terhadap para pelanggar hukum 1990, dan digunakan dalam Konvensi Wina tentang Pencegahan dan Pemberantasan Lalu Lintas Ilegal Narkotika dan Psikotropika 1988. Pengertian tersebut terakhir digunakan dalam Konvensi PBB Anti Kejahatan Transnasional Terorganisasi 2000, yang diartikan sebagai

\footnotetext{
2 Romli Atmasasmita, 2000, Pengantar Hukum Pidana Internasional, Penerbit Refika Aditama, Bandung, hlm. 35

3 Romli Atmasasmita, Ekstradisi dalam Meningkatkan Kerjasama Penegakan Hukum, Jurnal Hukum Internasional, Lembaga Kajian Hukum Internasional Fakultas Hukum Universitas Indonesia, Vol. 5 Nomor 1 Oktober 2007, hlm. iii
}

kejahatan yang memiliki karakteristik, sebagai berikut:

a. terjadi di dua Negara atau lebih

b. pelaku atau korban warga negara asing

c. sarana melampaui batas teritorial satu atau dua negara

Oppenheim bersama dengan Sir Arnold Mc Nair, telah membedakan secara tajam antara pengertian, "international delinquencies" di mana pengertian ini dimaksudkan sebagai hal yang bukan merupakan suatu kejahatan, sedangkan "international crimes" diartikan sebagai kejahatan. Pengertian "international delinquencies", diakui di dalam hukum kebiasaan internasional dan pengertian "international crimes" berkaitan dengan struktur hukum internasional.

Pengertian kejahatan internasional atau international crimes, adalah: ${ }^{4}$

"International Crimes is any con-duct which is designated as a crime in a multilateral convention with $a$ significant number of state parties to it, provided the instrument contains one of ten penal characteristic"

Kejatahatan internasional dapat diartikan sebagai semua perbuatan yang dilarang oleh hukum internasional, baik yang diatur di dalam konvensi maupun kebiasaan internasional. Ciri-ciri ter-penting dari kejahatan internasional adalah berlakunya asas universal, di mana setiap negara berwenang untuk menangkap, menahan, dan menuntut para pelaku kejahatan internasional.

Bassiouni menunjukkan adanya sepuluh karakteristik kejahatan internasional sebagai berikut: ${ }^{5}$

a. Explicit recognition of proscribed conduct as constituting an international crime a crime under international law;

b. Implicit recognition of the penal nature of an act by establishing a duty to prohibit, prevent, prosecute, punish, or the like;

c. Criminalization of the proscribed conduct;

d. Duty or right to prosecute;

\footnotetext{
${ }^{4}$ M Cheriff Bassiouni, International Criminal Law, Vol. I: Crimes, Transnational Publishers, New York, 1986, hlm. 2-3

5 Ibid
} 
e. Duty and right to punish the proscribed conduct;

f. Duty or right to extradite;

g. Duty or right to cooperation in prosecution, punishment (including judicial assistance in penal proceeding);

h. Establishment of a criminal jurisdiction basis;

$i$. Reference to the establishment of an international criminal court;

$j$. Elimination or the defense of superior order.

Dari kesepuluh karakteristik mengenai kejahatan internasional/international crimes tersebut di atas, dapatlah dikemukakan adanya tiga unsur utama berkaitan dengan hubungan antara kejahatan internasional dengan hukum pidana nasional atau hubungan antara hukum internasional dengan hukum nasional.

Adapun unsur tersebut adalah:

a. Adanya kewajiban negara untuk mengimplementasikan hukum internasional ke dalam hukum nasional atau melakukan kriminalitas kejahatan internasional ke dalam hukum pidana nasional;

b. Adanya kewajiban setiap Negara untuk melakukan kerjasama dalam pemberantasan kejahatan internasional;

c. Penegakan kejahatan internasional dapat di lakukan melalui pengadilan nasional maupun melalui pengadilan internasional.

Berdasarkan ciri-ciri tersebut, maka kejahatan transnasional, baik terorganisasi mau pun tidak terorganisasi merupakan bagian dari kejahatan inter-nasional. Sebab pada prinsipnya kejahatan transnasional menggunakan sarana atau prasarana melampaui batas wilayah negara. Kejahatan itu sendiri di dalamnya terdapat juga unsur transnasional.

Adapun unsur-unsur kejahatan internasional adalah:

a. unsur internasional:
1) direct threat to world peace and security
2) indirect threat to the world peace and security
3) shocking to the conscience of humanity

b. unsur transnasional:
1) conduct effecting more than one state

2) conduct including of affecting citizens of more than one state

3) means and methods transcend national boundaries

c. unsur kemampuan: cooperation of state necessity to enforce. ${ }^{6}$

Penggunaan istilah transnasional, khusus dipergunakan untuk menunjukkan kejahatan yang dilakukan oleh individu, di mana terhadap kejahatan itu sendiri, individu dapat dibebani tanggung jawab berdasarkan hukum nasional maupun hukum internasional. Pelaku kejahatan internasional harus dibedakan dengan kejahatan internasional yang pelakunya adalah Negara. Hal ini disebabkan bahwa Negara hanya dapat dibebani tanggung jawab kriminal internasional (international criminal responsibility of states) karena melanggar hukum internasional.

Rolling yang kurang sependapat dengan Bassiouni menegaskan bahwa penetapan suatu tindakan sebagai international crimes tidak perlu harus dipandang dari segi ada atau tidak adanya tindakan penjatuhan pidana di dalam keadaan nyata. Pendapat tersebut dilandasi dua hal, yaitu: ${ }^{7}$

a. situasi saat ini belum kondusif untuk melaksanakan tindakan penjatuhan pidana demikian (bahkan sudah sejak lama pakarpakar hukum internasional menghindari penggunaan instrumen pidana atas tindakan negara yang digolongkan sebagai inter-national crimes);

b. perasaan atau kebanggaan nasionalisme yang masih sangat kuat di kalangan bangsabangsa (bahkan untuk selamanya) merupakan kendala untuk dapat menerima begitu saja jurisdiksi (pidana) internasional.

2. Mutual Legal Assistance Treaties (MLATs) sebagai Instrumen Pemberantasan Kejahatan Internasional

Masa sebelum tahun 1980-an, dunia nyaris hampir tenggelam dalam peperangan dengan menggunakan persenjataan yang canggih (sophisticated weapons) terutama adu senjata

\footnotetext{
6 Kartini Sekartaji, Bahan Kuliah 2006, hlm. 2

Romli Atmasasmita, Op. Cit, hlm. 39
} 
oleh kedua belah pihak raksasa dunia di bidang persenjataan antara Amerika Serikat dan Soviet, yang kedua Negara itu disebut "the Super Power". Sejak berakhirnya era perang dingin atau post-cold war dunia tidak lagi berperang melawan senjata, terutama setelah runtuhnya The Super Power from The East, Soviet, dunia berperang melawan kesulitan ekonomi. ${ }^{8}$

Prosedur penegakan hukum terhadap kejahatan internasional termasuk masalah perkembangan kerjasama bilateral maupun multilateral di dalam mencegah dan memberantas tindak pidana internasional. Salah satu contoh penegakan hukum yang dilakukan dengan kerjasama yang tertua dalam praktik hukum internasional adalah ekstradisi.

Undang-undang Nomor 1 Tahun 1979 tentang Ekstradisi mengandung asas resiprositas, yang meliputi tiga hal yaitu:

a. Ada kepentingan politik yang sama (mutual interest);

b. Ada keuntungan yang sama (mutual advantages);

c. Ada tujuan yang sama (mutual goals) dan penghormatan atas asas "state souvereignty"

Implementasi asas resiprositas tidak memerlukan suatu perjanjian (treaty), tetapi cukup dengan "arragement" saja yang hanya berlaku atas dasar "on case by case basis". Guna kelancaran pe-laksanaan "arragement" diperlukan ke-tentuan yang menegaskan bahwa prosedur "non-treaty based" diperbolehkan dan dicantumkan dalam undang-undang.

Ekstradisi dapat diartikan sebagai penyerahan yang dilakukan secara formal baik berdasarkan atas perjanjian ekstradisi yang sudah ada sebelumnya ataupun berdasarkan prinsip timbal balik atau hubungan baik, atas seseorang yang dituduh melakukan kejahatan (tersangka, terdakwa, ter-tuduh) atau seseorang yang telah dijatuhi hukuman pidana yang telah mempunyai kekuatan mengikat yang pasti (terhukum dan terpidana), oleh tempatnya berada (negara diminta) kepada negara yang me-

\footnotetext{
8 Syafrinaldi, 2006, Hukum Internasional Antara Harapan Dan Kenyataan, Pekanbaru, Riau: Penerbit Uir Press, hlm. 66
}

miliki yurisdiksi untuk mengadili atau menghukumnya (negara peminta), atas permintaan dari negara peminta, dengan tujuan untuk mengadili dan atau pelaksanaan hukum-an. ${ }^{9}$

Adapun beberapa unsur ekstradisi berdasarkan uraian di atas, sebagai berikut: ${ }^{10}$

a. Unsur subjek, yaitu negara diminta dan negara/negara-negara peminta;

b. Unsur objek, yaitu orang yang diminta, yang bisa berstatus sebagai tersangka, tertuduh, terdakwa maupun terhukum ;

c. Unsur prosedur atau tata cara, yaitu harus dilakukan menurut prosedur atau tata cara atau formalitas tertentu, dan

d. Unsur tujuan, yaitu untuk tujuan mengadili dan atau penghukumannya.

Permintaan untuk menyerahkan itu harus dilakukan melalui saluran diplomatik. Demikian pula jika negara diminta menyetujui atau menolak permintaan negara peminta, maka harus memberitahukannya kepada negara peminta dengan melalui saluran diplomatik. Mengenai keputusan untuk mengabulkan ataupun menolak permintaan dari negara peminta, pejabat tinggi dari negara diminta, seperti: Jaksa Agung, Kepala Kepolisian, Menteri Kehakiman, maupun Menteri Luar Negeri ikut terlibat dalam memberikan pertimbangan, untuk akhirnya diambil keputusan oleh pejabat yang berwenang dari negara diminta.

Selain ekstradisi, bentuk kerjasama antar negara dalam praktik hukum kebiasaan internasional dapat dilakukan melalui Mutual Legal Assistance Treaties (MLATs). Bentuk kerjasama ini muncul di dalam praktik pemberantasan kejahatan internasional, yang bersifat transnasional ataupun kejahatan internasional sebagai tindakan pelaksanaan perjanjian lain, yang selama ini telah dilakukan di antara Negara-negara yang terlibat di dalamnya.

Sejarah pembentukkan kerjasama dalam bentuk Mutual Legal Assistance Treaties (MLATs) ini merupakan sejarah terpanjang yang pernah terjadi dalam praktik hukum internasional. Perjanjian diawali dengan perjanjian antara pe-merintah Amerika Serikat dan

\footnotetext{
9 I Wayan parthiana, Op. Cit, hlm. 129

${ }^{10}$ Ibid
} 
pemerin-tah Swiss. Perundingan antara wakilwakil pemerintah kedua Negara dilaku-kan sejak tahun 1972, ditandatangani pada tahun 1973, serta berlaku efektif pada tahun 1977 (setelah 50 tahun).

Tindak lanjut dari perjanjian tersebut, pada tanggal 10 November 1987 telah ditanda tangani suatu Memorandum of Understanding (MoU) antara pemerintah kedua negara untuk menambah/melengkapi ketentuan-ketentuan yang sudah dicantumkan dalam MLATs tahun 1973 antara kedua negara. MoU tersebut di namakan MoU on Mutual Assistance in Criminal matters and Ancillary Administrative proceedings. ${ }^{11}$

Berbagai perjanjian internasional, baik perjanjian bilateral maupun perjanjian multilateral telah disepakati sebagai salah satu cara yang paling niscaya dalam internationally coordinated efforts to combat international crimes. Bentuk-bentuk kerjasama internasional, seperti Mutual Legal Assistance Treaties (MLATs) sudah semakin banyak disepakati, misalnya yang diatur cukup komprehensif dalam United Nations Convention Against Corruption Tahun 2003, United nations Conventions Against Transnational Organized Crime Tahun 2000. Sedangkan pada tingkat Regional ASEAN, telah disepakati Treaty Mutual Legal Assistance in Criminal Matters tahun 2004. Perjanjianperjanji-an seperti tersebut di atas tentu saja sangat menghormati jurisdiksi dan mengandalkan ketentuan hukum nasional dari negara pesertanya. Namun dibutuhkan tindakan dan aturan untuk meng-koordinasikan kegiatan-kegiatan nasional tersebut sehingga semakin meningkat sejalan dengan tumbuh dan berkembangnya kejahatan-kejahatan internasional.

Selain itu penegakan dapat dilakukan dengan melalui kerja sama internasional atau mutual legal assistance treaty atau judicial assistance treaty antara dua negara atau lebih, sebagaimana dilaksanakan telah dilaksanakan, khususnya di antara negara-negara ASEAN serta antara pemerintah Amerika Serikat dan Swiss, jerman, Belanda, Meksiko, Panama, Nikaragua,

\footnotetext{
${ }^{11}$ Romli Atmasasmita, Op. Cit., hlm. 26
}

dan Italia. Contoh lain, usaha-usaha masyarakat internasional atau Negara-negara dalam mencegah dan memberantas kejahatan transnasional dapat dilakukan dengan kerjasama secara fisik maupun dengan menuangkan pengaturannya dalam konvensi-konvensi internasional yang sudah lama berlaku. ${ }^{12}$

Beberapa konvensi internasional yang bertalian dengan kejahatan transnasional tersebut, antara lain:

a. Konvensi London 1945 tentang Agreement of the Prosecution and Punishment of the Major War Criminal of the European Axis yang melahirkan Mahkamah Militer Internasional (International Militery Tribunal) di Nurenberg 1946, yang diadakan oleh negaranegara pe-menang Perang Dunia Kedua sedangkan di Tokyo 1948. Peradilan ini dimaksudkan untuk mengadili pelaku kejahatan terhadap kemanusiaan dan perdamaian yang telah banyak mengakibatkan kerugian bagi umat manusia di atas bumi ini. Pasal 6 Piagam Mahkamah menyebutkan, bahwa "Mahkamah ... mempunyai wewenang untuk mengadili dan menghukum orang-orang yang bertindak untuk kepentingan negara-negara poros (axis) baik sebagai individu maupun sebagai anggota organisasi yang melakukan kejahat-an-kejahatan".

Terhadap pembentukan Mahkamah Militer Internasional ini banyak yuris mengecamnya karena pengadilan ini mengadili perkara dengan hukum yang diberlakukan surut (retroaktif) atau ex post pacto law yaitu hukum yang dibentuk setelah terjadinya peristiwa. Jadi bertentangan dengan asas nullum delictum nula poena sine praevia lege poenali.

b. Konvensi Genosida 1948 yang lengkapnya bernama Convention on the Prevention and Punishment of the Crime of Genocide yang di-prakarsai oleh PBB dan mulai berlaku pada tahun 1951.

Konvensi ini mendefinisikan genocide sebagai tindakan yang dilakukan dengan maksud merusak dan memusnahkan suatu ke-

\footnotetext{
12 I Wayan Parthiana, 2004, Op. Cit, hlm. 42
} 
lompok bangsa, etnis, ras atau agama dengan jalan membunuh anggota kelompok tersebut yang mengakibatkan kerugian bagi mereka secara fisik dan mental. Dengan sengaja melakukan penyiksaan terhadap keadaan jiwa, melakukan tindakan-tindakan yang bersifat memaksa untuk mencegah perkembangbiakan mereka atau keturunan, memindahan secara paksa anak-anak kelompok tersebut ke dalam kelompok lainnya.

c. Konvensi-konvensi tentang penghapusan perbudakan seperti misalnya Slavery Convention tahun 1926 yang ditambah dan diperbaharui pada tahun 1953 disempurnakan pada tahun 1956 atas inisiatif ECOSOC.

Berdasarkan konvensi ini para pihak sepakat akan menyusun perundang-undangan nasional yang efektif serta akan melakukan tindakan-tindakan demi terhapusnya praktikpraktik perbudakan, atau yang berhubungan dengan itu seperti utang perbudakan, jual beli manusia, eksploitasi tenaga anak-anak dan penjualan budak-budak antaranegara. Para pelakunya harus diadili dan dihukum dengan hukuman berat.

d. Konvensi tentang Laut Lepas 1958 pada Pasal 14 sampai dengan Pasal 22 mengatur Pembajakan di laut lepas yang merupakan pembajakan menurut hukum internasional (piracy jure gentium) yang berbeda dengan pengertian pembajakan menurut hukum nasional.

Pasal 14 menyebutkan bahwa semua negara harus bekerjasama yang sepenuhnya dan seluas-luasnya dalam memberantas kejahatan di laut lepas atau di tempat-tempat lain di luar yurisdiksi negara. Sedangkan Pasal 15 menegaskan bahwa batas-batas pengertian piracy jure gentium ini yang membedakannya dengan pembajakan menurut hukum nasional.

e. Tiga konvensi yang berkenaan dengan kejahatan penerbangan yakni:

1) Konvensi Tokyo 1963 tentang Offences and Certain Other Acts Committed on Board Aircraft (Kejahatan-kejahatan dan tin-dakan-tindakan tertentu lainnya yang dilakukan dalam pesawat udara)
2) Konvensi Den Haag 1970 tentang The Suppression of Unlawful Seizure of Aircraft (Pemberantasan Penguasaan Pesawat Udara Secara Melawan Hukum)

3) Konvensi Montreal 1971 tentang The Suppression of Unlawful Acts Against the Safety of Civil Aviation (Pemberantasan Tindakan-tindakan Melawan Hukum yang Mengancam Keamanan Penerbangan Sipil) Ketiga konvensi ini pada dasarnya adalah konvensi yang bertujuan mencegah kejahatan penerbang-an.

f. Single convention on Narcotic Drugs 1961 atau Konvensi Tunggal tentang Narkotika serta protokol yang mengubahnya, yang di adakan di New York pada tahun 1961. Narkotika di samping berguna untuk pengobatan dan ilmu pengetahuan, sebaliknya narkotika dapat pula mengakibatkan ketergantungan yang sangat merugikan apabila penggunaannya tanpa pembatasan dan pengawasan secara seksama.

Kejahatan ini tidak hanya membahayakan perorangan melainkan juga masyarakat, bangsa dan negara. Pasal 13 Protokol yang mengubah Pasal 35 dari Konvensi Tunggal menyebutkan bahwa mewajibkan setiap pihak sesuai dengan hukum ketatanegaraannya, sistem hukum dan sistem administrasinya untuk mengadakan suatu koordinasi tingkat nasional guna mengambil tindakan pencegahan dan pemberantasan terhadap lalu lintas narkotika, membantu setiap kampanye yang bertujuan mencegah lalu lintas narkotika, serta bekerjasama satu dengan lainnya dan dengan badan-badan internasional yang ber-kompeten.

Dari beberapa konvensi yang dibuat oleh negara-negara dalam menanggulangi kajahatan internasional memperlihatkan bahwa kerjasama internasional dirasakan oleh negara-negara lebih efektif. Oleh karena itu, negara-negara di dunia cenderung untuk mencegah dan memberantasnya melalui kerjasama internasional dan mengaturnya dalam konvensi-konvensi internasional. Konvensi-konvensi itu ada yang secara khusus mengatur tentang kejahatan transnasional itu, ada pula yang mengaturnya 
bersama-sama dengan masalah lain yang lebih luas.

\section{Penutup}

1. Simpulan

Upaya penegakan hukum terhadap kejahatan internasional dapat dilakukan melalui perjanjian ekstradisi. Selain itu juga dengan perjanjian internasional lain baik bilateral maupun multilateral, atau mutual legal assistance treaty atau judicial assistance treaty antara dua Negara atau lebih.

Mutual Legal Assistance Treaties (MLATs) pun muncul karena pem-berantasan kejahatan tidak cukup di-tegakkan dengan perjanjian ekstradisi. Bentuk Mutual Legal Assistance Treaties (MLATs) sudah semakin banyak disepakati, misalnya United Nations Convention Against Corruption Tahun 2003, United nations Conventions Against Transnational Organized Crime Tahun 2000. Sedangkan pada tingkat Regional ASEAN, Treaty Mutual Legal Assistance in Criminal Matters tahun 2004.

\section{Saran}

Perkembangan teknologi dalam masyarakat internasional sangat mempengaruhi pula perkembangan kejahatan internasional. Oleh karena itu, akan lebih efektif bila negara-negara mencegah dan memberantasnya melalui kerjasama/perjanjian inter-nasional dan mengaturnya dalam konvensi-konvensi internasional.

\section{Daftar Pustaka}

Atmasasmita, Romli. 2000. Pengantar Hukum Pidana Internasional. Bandung: Refika Aditama;

Parthiana, I Wayan. 2002. Hukum Per-janjian Internasional Bag: 1. Bandung: Mandar Maju;

2004. Hukum Pidana Inter-nasional Dan Ekstradisi. Bandung: CV. Yrama Widya;

2005. Hukum Perjanjian Internasional Bag: 2. Bandung: Mandar Maju;

Starke, J.G.. 1986. An Introduction To International Law. Diterjemahkan oleh Justisi Study Group dengan judul Peng- antar Hukum Inter-nasional. Bandung: Justisi Study Group;

Syafrinaldi. 2006. Hukum Internasional Antara harapan dan Kenyataan. Pekanbaru, Riau: UIR Press;

Thontowi, Jawahir dan Pranoto Iskandar. 2006. Hukum Internasional Kontemporer. Bandung: Refika Aditama;

Sekartaji, Kartini. 2006. Bahan Kuliah Hukum Pidana Internasional;

Jurnal Hukum Internasional. Indonesia Journal of International Law - Treaties. Volume 3 Nomor 4 Oktober 2006;

Jurnal Hukum Internasional. Indonesia Journal of International Law -International Crime. Volume 5 Nomor 1 Oktober 2007;

Jurnal Hukum Internasional. Indonesia Journal of International Law - Treaty and National Law. Volume 5 Nomor 3 April 2008. 
110 Jurnal Dinamika Hukum

Vol. 9 No. 2 Mei 2009 